\title{
Entre tempos e mundos: Chateaubriand e a outra América
}

Between Times and Worlds:

Chateaubriand and the other America

\section{Wilma Peres Costa}

Livre Docente de História do Brasil na Universidade Federal de São Paulo (Unifesp - Guarulhos)

e-mail:wilma_peres@uol.com.br

\section{Resumo}

Buscando refletir a partir dos ensinamentos do historiador francês François Hartog, o trabalho aborda as relações entre a Europa e as Américas na Era das Revoluções, através dos escritos produzidos por René de Chateaubriand, sobre o Congresso de Verona (1822) e a intervenção militar francesa na crise espanhola (1823). Ao estudar o modo como a emergência das novas nações americanas aparece nos escritos e na ação política de Chateaubriand, buscamos compreender o modo pelo qual aquela experiência incidiu sobre suas concepções em relação ao tempo, às revoluções antigas e modernas e a própria história.

\section{Abstract}

The article deals with the relations between Europe and America in the Age of Revolutions, through the writings of René de Chateaubriand on the Congress of Verona (1822) and the French military intervention in Spanish crisis (1823), inspired by the teachings of the French historian François Hartog. By means of the study of the way the new American nations appear in Chateaubriand's writings and political action, we try to explore the role played by that experience in his conceptions of time, of the ancient and modern revolutions and History itself.

\section{Palavras-chave}

Europa, América, revolução, monarquia, república / republicanismo

\section{Keywords}

Europe, America, revolution, monarchy, republic / republicanism 
L'époque où nous vivons est essentiellement propre à l'histoire : placés entre deux empires dont l'un finit et dont l'autre commence, nous pouvons porter également nos regards sur le passé et dans l'avenir. II reste encore assez de monuments de l'ancienne monarchie pour la bien connaître, tandis que les monuments de la monarchie qui s'élève nous offrent au milieu des ruines le spectacle d'un nouvel univers. Nous-mêmes, avec nos malheurs et nos crimes, nous venons nous placer dans ce tableau; du moins, si notre siècle est peu fécond en grands hommes et en grands exemples, il est fertile en grands événements et en grandes leçons.

(René de Chateaubriand, Le Conservateur, 8 janvier 1819)

1

A grande referência na historiografia brasileira é NOVAIS, Fernando. Portugal e Brasil na crise do Antigo Sistema Colonial (1777-1808). São Paulo: Hucitec, 1974. Outra perspectiva do enlace entre a crise do Antigo Regime e a do Antigo Sistema Colonial teve um tratamento aprofundado em Jacques Godechot, que celebrizou o termo "revolução atlântica". Ver: GODECHOT, Jacques. As Revoluções: 1770-1799. Trad. Port. São Paulo: Pioneira, 1976; Idem. Europa e América no tempo de Napoleão, (1800/1815). São Paulo: Ed. Pioneira, 1984. Dentre os múltiplos interlocutores críticos indico alguns trabalhos referenciais, cada um deles com múltiplos desdobramentos historiográficos: ver ALEXANDRE, Valentim. Os Sentidos do Império. Porto: Afrontamento, 1993; e PEDREIRA, Jorge V. Estrutura Industrial e Mercado Colonial. Portugal e Brasil (1780-1930). Lisboa: DIFEL, 1994. No Brasil, ver FRAGOSO, João L.R. e FLORENTINO, Manolo. 0 Arcaismo como Projeto: mercado atlântico, sociedade agrária e elite mercantil em uma sociedade colonial tardia: Rio de Janeiro, c. 1790 - c. 1840 . Rio de Janeiro: Civilização Brasileira, 2001 e também FRAGOSO, João L.R. e GOUVEIA, Maria de Fátima (Eds.). Antigo Regime nos Trópicos - A Dinâmica Imperial Portuguesa (séculos XVI-XVIII). Rio de Janeiro: Ed. Civilização Brasileira, 2001.

\section{2}

A resignificação da discussão em termos atuais é devedora da incorporação de KOSELLECK, R., especialmente L'Experience de l'Histoire. Paris: Gallimard Le Seuil, 1997 (Futuro Passado, 1a. ed. brasileira S.P., Ed. Contraponto, 2006). Resignificando a discussão, em termos atuais ver JANCSÓ, István e PIMENTA, João Paulo Garrido. "Peças de um mosaico (apontamentos para o estudo da emergência da identidade nacional brasileira)". In: Viagem Incompleta. A experiência brasileira (1500-2000). São Paulo: SENAC São Paulo Ed., 2000, Vol.1. p.127-176. Um panorama da discussão que se irradia a partir dessa linhagem interpretativa pode ser visto nos vários capitulos de JANCSÓ, István (org.). Brasil: formação do estado e da nação. São Paulo: Hucitec, 2003.

\section{Apresentação}

As reflexões presentes nesse ensaio, extraídas de pesquisa em andamento, inserem-se no extenso debate sobre a articulação entre a Europa e as Américas na grande travessia que faz emergir o mundo contemporâneo, entre a última década do século XVIII e as primeiras décadas do século XIX. 0 tema, caro a uma fecunda linhagem de historiadores, engendrou na década de 1970, uma influente intepretação que conectava a crise do Antigo Regime europeu àquela do Antigo Sistema Colonial referida principalmente aos fundamentos econômicos - a ascensão do industrialismo inglês e seus efeitos inexoráveis na reorganização da economia-mundo. Ancorada principalmente no campo teórico do debate marxista, essa interpretação tem recebido fortes reparos, acompanhando de certo modo, a fortuna crítica da matriz teórica em que se assenta. A acerba polêmica que essa interpretação suscitou nas duas últimas décadas tem produzido um grande enriquecimento ao campo historiográfico, onde se destacam dois efeitos principais, geradores cada um deles, de linhagens interpretativas distintas, mas nem sempre opostas. 0 primeiro efeito tem sido o de propiciar novos e promissores caminhos para o entendimento dos fluxos econômicos no interior da América Portuguesa e entre as diversas partes do Império, bem como sobre as estratégias de inserção de Portugal e seu Império no interior da economia-mundo, a partir da segunda metade do século XVIII. ${ }^{1}$ Nessa linhagem, com múltiplas ramificações, tem se contestado a aplicabilidade da própria idéia de crise, para pensar os enlaces entre Portugal e suas possessões americanas. 0 segundo efeito, inversamente, atém-se com firmeza à idéia de " crise " e à sua pertinência heurística para compreender o enlace entre acontecimentos do velho e do novo mundo no nascimento da contemporaneidade. Deslocando, porém, o foco, do debate econômico, os historiadores têm procurado re-significar a noção de crise valendo-se dos procedimentos da história cultural e da nova história política, produzindo novas e sugestivas sinteses interpretativas.

Essa viragem tem feito reverter o olhar dos historiadores sobre as dimensões políticas e culturais da crise do Antigo Regime e suas conexões reversivas no Antigo e no Novo Mundo. Ela tem também engendrado uma atenção redobrada sobre os discursos e vocabulários políticos, como indícios da volatilidade própria das situações de crise e como trilhas abertas para a compreensão de sua complexidade. Caudatários de espaços de experiência em vertiginosa mutação e da práxis politicas de atores que a vivenciam em diferentes posições e perspectivas, os termos adquirem novos significados, que substituem usos antigos, ou, outras vezes, sobrepõem-se a eles, compondo sinteses desafiadoras para o trabalho do historiador. ${ }^{2}$ 
Cf. WALLERSTEIN, I. The Modern World-System. Vol. III: The Second Great Expansion of the Capitalist World-Economy, 1730-1840's. San Diego: Academic Press. 1989 xion française sur la diversité humaine. Paris: Seuil, 1989. p.241. Tradução livre, da autora.
A compreensão dessa mudança pressupõe a incorporação de duas ordens de reflexões. Em primeiro lugar, devemos ter em conta as mutações que se operavam, ao longo da crise, naquilo que se entendia como "nação", dentre elas a sobreposição de um conteúdo "cívico" (vale dizer político) a uma concepção etno-cultural da nacionalidade. Embora não seja possivel desenvolver aqui as múltiplas implicações desse tema, deve-se enfatizar que essa viragem, vivida em condições específicas, ocorreu simultaneamente no velho e no novo continente, articulando a emergência dos estados nacionais na Europa e na América, em um movimento de olhares cruzados, de experiências mutuamente referidas e de avaliações reciprocamente refletidas. Vale dizer, essa quadra história se conecta à emergência de paradigmas comparatistas de toda ordem, que impregnam as visões de mundo, espraiando-se do plano das ciências da natureza à escrita da história, movimento dialético que faz derivar os continentes, ao mesmo tempo em que conecta e aproxima os destinos políticos das nações nas várias partes do mundo em um sistema internacional de estados. Tal afirmação não sugere, evidentemente, um sistema equitativo de experiências trocadas, pois o mundo que se reordenava no movimento que se consolidava entre o Congresso de Viena (1815) e o Congresso de Verona (1822) estruturava-se como profundamente hierárquico e controlado por um rígido sistema de potências. Por outro lado, ele era também um mundo furiosamente competitivo, fato que uma visão economicista da hegemonia inglesa tende freqüentemente a obscurecer ${ }^{3}$.

Expressão privilegiada da sobreposição de sentidos referida acima, essa ordem imporia outra transformação fundamental nas práticas políticas referidas à idéia de nação: tornar-se "nação" e ter a soberania aceita como sistema internacional passou a implicar a conferência de um estatuto, um processo de reconhecimento no interior de um sistema internacional de estados, controlado pelas potências européias. 0 fenômeno afetava tanto as antigas nações do velho mundo (algumas das quais surgiram e desapareceram na Era dos Congressos e nos anos subseqüentes) como aquelas que emergiam no Novo Mundo, a partir da ruptura com suas metrópoles, fazendo com que o processo de construção nacional nos dois continentes se fizesse em concomitância e complexa reversividade ao longo do século XIX. No contexto europeu, o movimento resultou na periferização das antigas metrópoles ibéricas, mas também no surgimento de novas nações, como a Bélgica e a Grécia, bem como na exacerbação da rivalidade anglo francesa. Todorov, analisando essa metamorfose no plano da rivalidade européia, nos fala do deslizamento da idéia de nação de um sentido "interno" para um sentido "externo". A nação serve também de mediadora entre os diferentes povos, marcando assim menos a idéia de similitude do que a de diferença.

É preciso agora introduzir uma outra distinção entre dois sentidos da palavra " nação ", ambos de natureza política. Podemos designar um como " interno " e outro como " externo ". 0 primeiro sentido é aquele que iria assumir uma importância considerável às vésperas da Revolução Francesa e durante os seus primeiros anos. A nação é um espaço de legitimação e se opõe, enquanto fonte de poder, ao direito real ou divino ; executam-se ações em nome da nação, no lugar de se referir a Deus ou ao rei ; grita-se 'Viva a nação!' no lugar de 'Viva o rei' !. Este espaço é agora percebido como o espaço da igualdade (...) ; recorre-se à 'nação' para combater os privilégios sociais ou os particularismos regionais. 0 segundo sentido, o sentido 'externo' da palavra nação, é completamente diferente: uma nação se opõe desta feita à uma outra, não mais ao rei, ou à aristocracia, ou às regiões : os franceses são uma nação, os ingleses são outra. ${ }^{4}$ 
A viagem de Chateaubriand realizou-se em 1792, mas o relato, sob o título, Voyage en Amérique veio a luz na edição de suas "obras completas" em 1827 assim como Les Natchez., epopéia romântica sobre o destino trágico dos indigenas americanos frente à conquista européia. A América é presença constante em suas reflexões, acentuando-se, depois de 1826, a preocupação com a dimensão de seu papel na rivalidade anglo-francesa. 0 outro marco referencial da reflexão política suscitado pela experiência americana foi sem dúvida Alexis Tocqueville, em La Democratie en Amérique, (publicado entre 1835 e 1840 ) a partir da viagem realizada em 1830. Ver : RÉMOND, René. Les Etats-Unis devant l'opinion française 1815-1852. Paris: Armand Collin, 1962. 0 movimento de idéias que começa a tomar forma nas décadas de 1820 e 1830, a partir dos escritos de Chateaubriand e Tocqueville, ganha visibilidade maior em BEAULIEU, P. Leroy. De la colonisation chez les peuples modernes. Paris: Guillaumin, 1874

6

HARTOG, François. Régimes d'historicité - présentisme et expérience du temps. Paris: Seuil, 2003, especialmente cap. 3. Ver também Idem. Anciens, Modernes, Sauvages. Gallade Éditions, 2005.
Não por acaso, a resignificação que se operava nas primeiras décadas do século XIX sobre o conceito de nação, operava igualmente sobre as idéias referidas à colonização, articulando todo um gradiente de composições possiveis entre os significados dos termos " nação " e " colônia ", nos dois mundos. Nas emergentes nações americanas os termos passam a operar em registros opostos - a afirmação da condição nacional emergindo do rompimento com a condição de colônia, suplantando significados anteriormente vigentes que incorporavam possibilidades de composição entre identidades nacionais e o sistema imperial ibérico. No mundo europeu, especialmente no campo da rivalidade anglo-francesa, um intenso debate se processa sobre o significado passado e futuro dos processos de colonização. Eles se nutriam, em grande parte, das experiências nacionais que se processavam nas duas américas e iriam desembocar, a partir da década de 1830, na retomada da expansão colonial européia. No campo dos ideários, os grandes marcos do debate podem ser localizados a partir da publicação da obra seminal do Abade Raynal, contundente libelo contra o antigo colonialismo, espraiando-se em rica e diversificada polêmica sobre a experiência colonial do velho mundo, suas lições e perspectivas para as emergentes potências européias. 0 passado da colonização, sua crise e superação, vieram, assim, a alimentar os novos projetos de colonização e emigração dos europeus, criando um enquadramento peculiar para a compreensão das experiências nacionais americanas. Estas, por sua vez, fariam suas própria leituras do debate, introjetando em seus territórios lições específicas sobre a articulação interna entre imigração e colonização vistas agora como políticas dos novos estados independentes na conformação das novas nações americanas. A transformação que se opera então, entre a visão do passado, o presente e o futuro, entre antigos e modernos articula também a relação entre velho mundo e novo mundo, criando uma ponte entre as antigas e as novas teorias da colonização. Transitando entre os dois mundos, viajantes e seus relatos são vetores privilegiados na construção desses olhares cruzados e das metamorfoses semânticas antes referidas. No campo intelectual francês, invertendo a direção das severas reflexões do Abade Raynal, as visões da América demarcadas a partir da Voyage en Amérique de Renée de Chateaubriand (1827) e La Démocratie en Amérique de Alexis de Tocqueville (1835-1840) estabeleceram algumas das balizas dessa discussão e seriam apropriadas em diversas chaves nos dois continentes ${ }^{5}$.

Este é tema vasto, para longo e demorado esforço de pesquisa. Menciono-o aqui para indicar o contexto das indagações que suscitaram esse trabalho, que tem objetivos bem mais modestos. Ele é um exercício de reflexão a partir das sugestões contidas nos trabalhos do historiador francês François Hartog sobre a Teoria da História e o lugar nelas atribuído à viagem como processo de construção do conhecimento, focalizando particularmente a viragem produzida pela escrita de René de Chateaubriand. 6

Neles, a articulação entre os continentes aqui mencionada aparece cristalizada nessa escrita, como momento chave na elaboração de uma nova percepção do tempo e do devir histórico própria da contemporaneidade (o novo regime de historicidade) e que esta é caudatária não apenas da vertiginosa aceleração do tempo gerada pela Revolução Francesa, mas também da alteridade propiciada pela viagem à América e expressa na narrativa feita por Chateaubriand dessa experiência. Alargando e aprofundando uma sugestão oferecida por Koselleck, essa rica e complexa 
7

Ver KOSELLECK, Reinhardt. L'Experience de I'Histoire. Paris : Gallimard Le Seuil, 1997. p.239. (Futuro Passado, 1a. ed. brasileira S.P., Ed. Contraponto, 2006).

8

Os escritos sobre o Congresso de Verona vieram à luz, pela primeira vez, em 1838. Ver CHATEAUBRIAND, François-René de. Congrès de Vérone. Guerre d'Espagne. Négociations. Colonies espagnoles. Edition originale, Leipzig. Paris: Brockhaus, Avenarius, 1838. Uma primeira edição das Memórias foi publicada em 1841. A edição utilizada aqui é a das Oeuvres complètes, vol. 12, Le congrès de Vérone; Guerre d'Espagne Fac-sim. de l'éd. de Paris : Garnier, [s.d.], (prob. 1861). Para um profundo e erudito estudo sobre a obra politica de Chateaubriand ver a Introdução do especialista CLÉMENT, Jean Paul em Chateaubriand politique - François-René de Chateaubriand De I'Ancien Régime au Nouveau Monde- Ecrits politiques. Paris: Hachette, 1997. Do mesmo especialista, ver a introdução de François-René de Chateaubriand, Grands écrits politiques. Paris: Imprimerie National, 2005.

9

Sobre as relações entre letrados e política no periodo ver BÉNICHOU, Paul. Le sacre de l'écrivain 1750-1830, Essai sur l'avènement d'un pouvoir spirituel lä̈que dans la France moderne. Paris: Librairie José Corti, 1973. Especificamente sobre Chateaubriand ver BERGER, Guy. Chateaubriand et la politique. Numéro Hors-Serie, "Politique et Littérature". La revue des Anciens Élèves de l'Ecole Nationale d'Administration, Décembre 2003, publicação disponivel em http://www.karimbitar. org/chateaubriand_guyberger, acessado em 03 de janeiro de 2010. interpretação institui o grande literato como expressão privilegiada do movimento de viagens que atraiu de forma singular em toda a Europa uma camada de jovens letrados, parte significativa deles era composta de vencidos da revolução, ${ }^{7}$ figuras de procedência nobre e variada condição de fortuna, que buscaram nas viagens ao Novo Mundo, um modo de evitar os efeitos mais desafiadores da tormenta revolucionária. A experiência do dépaysement e da alteridade converge aí com a do alargamento da percepção do devir histórico, visto como travessia entre tempos que não mais retornam, liberta da repetição do passado e aberta ao desconhecido. Em erudita e fascinante exploração dos escritos de Chateaubriand, François nos mostra especialmente o efeito da inquietante percepção da convivência, na América, de distintas temporalidades históricas, experimentada ao longo de sua curta estadia no continente americano. A busca pela liberdade primitiva, encontrada e perdida no convivio com os indigenas norteamericanos, terminava pela descoberta da importância da constituição e da "liberdade dos modernos", estabelecendo uma démarche fundamental para a transição entre a concepção antiga e a moderna de história que Hartog sugestivamente denomina como passagem de um paradigma interpretativo fundado no paralelo entre os acontecimentos do presente e os do passado, para um outro, em que a comparação adquire papel central, aproximando a disciplina histórica do grande movimento científico do século XIX. 0 passado próximo e as dinâmicas sincrônicas ganham aí precedência sobre as lições extraídas dos tempos remotos e das narrativas da história antiga.

Acolhemos este caráter paradigmático da contribuição de Chateaubriand como "pensador do tempo", condição que se afirma, sem prejuizo do fato de que ele não fosse, no rigor do termo, um historiador, mas um talentoso homem de letras, um fecundo pensador político e, por um curto e intenso período de sua vida atribulada, um homem de ação. Enfatizando este último aspecto, o diálogo que aqui se propõe, foi nos sugerido pelos escritos de Chateaubriand sobre a América, produzidos durante e após a sua mais importante experiência como estadista, a condição de plenipotenciário francês no Congresso de Verona (1822), momento em que se decidiu a invasão francesa da Espanha e ato final da independência das colônias espanholas da América8.

A breve e intensa carreira política de Chateaubriand havia se iniciado timidamente sob Napoleão, mas veio a florescer plenamente com a Restauração. Sob Luis XVIII, ele ocupou sucessivamente as embaixadas de Berlim e Londres (1821), foi Ministro Plenipotenciário no Congresso de Verona (1822) e Ministro dos Negócios Estrangeiros (1823). Afastado dos cargos governamentais desde então, manteve sempre a lealdade expressa aos Bourbons, levando-o à oposição a partir da Monarquia de Julho, e até mesmo a uma relativa aproximação com os círculos republicanos. Sua trajetória permite visualizar a significação de novos caminhos de peregrinação que levavam os homens de letras para postos elevados do poder político na nova ordem, atendendo exigências que operavam tanto no interior da vida interna dos estados, como nos cenários da diplomacia. ${ }^{9}$

Entre 1822 e 1823, momento final da grande crise que envolvia a Espanha e suas colonias na América, Chateaubriand foi personagem chave na decisão da intervenção armada na Espanha (para restabelecer o poder de Fernando VII, ameaçado pela rebelião das Cortes). Intervenção que se propunha em abragência nos dois continentes, a situação possibilitou também ao grande escritor registrar suas impressões sobre o continente 
americano em grande abrangência, focalizando os movimentos de rebeldia dos colonos da América Espanhola, sua relação com as potências européias e com a já consolidada República dos Estados Unidos da América.

0 protagonismo assumido por Chateaubriand na crise espanhola e seus efeitos sobre o conjunto da América que mais tarde seria denominada de "latina" sugerem a relevância de indagar sobre as percepções por ele registradas sobre essa "outra América". Assim, perseguindo na senda aberta por François Hartog e permanecendo no território da rica obra de François Chateaubriand, incorporamos esse espaço de experiência representado pelo Congresso de Verona e pelas decisões referidas à Guerra de Espanha (e seus efeitos), e nos perguntamos como ele foi traduzido em sua escrita, suscitando outras dimensões à sua percepção do tempo histórico, sobre a natureza das revoluções e principalmente, sobre os modos pelos quais 0 comparatismo aqui se exercita.

Tal recurso nos parece produtivo para pensar o modo como a ação e o pensamento convergiram na vida dessa personagem singular, condensando a contundência e a natureza contraditória das transformações em curso. Assim nos pareceu, inicialmente necessário reconstituir o lugar da fala de Chateaubriand sobre a "outra América", lugar que nos parecia evidentemente distinto daquele onde ele se colocara para falar da América do Norte. Buscávamos distinguir o jovem e inquieto viajante de 1791, do ressentido e torturado polemista de 1826, que se recolhia de volta ao mundo das letras, decepcionado com a perda do seu breve e intenso protagonismo político, como Ministro Plenipotenciário da França no Congresso de Verona (1822). Focalizando os escritos que Chateaubriand nos deixou sobre a intervenção francesa na crise espanhola (e sobre sua articulação com a emergência dos novos estados nações da América) procuramos compreender como eles também se mesclaram na cristalização do novo regime de historicidade - a vigência do tempo das comparações.

A evidência que perseguimos aqui provém também de outra constatação. 0 grande movimento empreendido por Chateaubriand no sentido de afastar-se da vida pública e empreender a publicação de sua obra parece ter se dado precisamente como resultante dessa grande decepção política que foi a sua passagem pelo Ministério entre 1822 e 1823, após a emergência da " outra " América no sistema internacional. A convergência entre a escrita da memória, reflexão sobre a praxis política, e reinvenção da vida que encontramos nesses trabalhos nos convencem de que eles tem um peso excepcional na configuração de seu pensamento, tendo em conta que a decisão de sua publicação pertence a essa mesma viragem que, afastando Chateaubriand da política institucional, levou-o à revisão explícita de algumas de suas posições e ao início da escrita de sua auto-biografia, da qual a Guerra de Espanha forma uma espécie de intróito.

\section{Repensando o tempo e as revoluções antigas e modernas}

É relevante ressaltar aqui a distância entre a experiência da viagem à América (1792) e a publicação de seu relato (1827), e apontar sua proximidade com um outro escrito, também ele paradigmático na reflexão sobre o tempo na obra de Chateaubriand. Refiro-me ao Ensaio sobre as Revoluções Antigas e Modernas, curioso trabalho escrito logo após seu retorno da América, demarcado pela tentativa fracassada de envolver-se na defesa da monarquia e pela perda da maior parte da sua familia durante os anos mais férvidos da Revolução. A primeira versão do Ensaio sobre as 


\section{0}

"Lorsque je quittai la France j'étais jeune : quatre ans de malheur m'ont vieilli. Depuis quatre ans, retiré à la campagne, sans un ami à consulter, sans personne qui pût m'entendre, le jour travaillant pour vivre, la nuit écrivant ce que le chagrin et la pensée me dictaient, je suis parvenu à crayonner cet Essai. Je n'en ignore pas les défauts; si le moi y revient souvent,c'est que cet ouvrage a d'abord été entrepris pour moi, et pour moi seul. On y voit presque partout un malheureux qui cause avec lui-même; dont l'esprit erre de sujet en sujet, de souvenir en souvenir ; qui n'a point l'intention de faire un livre, mais tient une espèce de journal régulier de ses excursions mentales, un registre de ses sentiments, de ses idées. Le moi se fait remarquer chez tous les auteurs qui, persécutés des hommes, ont passé leur vie loin d'eux. Les solitaires vivent de leur coeur, comme ces sortes d'animaux qui, faute d'aliments extérieurs, se nourrissent de leur propre substance. CHATEAUBRIAND, François-René de. Essai historique, politique et moral sur les révolutions anciennes et modernes, considerées dans leurs rapports avec le révolution françoise. ed. 1826. In : Oeuvres Completes (Garnier, 1861), doravante citado como Essai sur les Révolutions, p.266

11

"Je commençai à écrire l'Essai en 1794, et il parut en 1797. Souvent il fallait effacer la nuit le tableau que j'avais esquissé le jour : les événements couraient plus vite que ma plume : Il survenait une révolution qui mettait toutes mes comparaisons en défaut ; j'écrivais sur um vaisseau pendant une tempête, et je prétendais peindre comme des objets fixes les rives fugitives qui passaient et s'abîmaient le long du bord ! ».CHATEAUBRIAND, François-René de. Essai sur les Révolutions, p.249.
Revoluções, iniciada em 1794, no exílio, na Inglaterra, e publicada em 1797, era uma espécie de recorrido das revoluções da antiguidade clássica postas em paralelo com a revolução que presentemente se desenrolava na Europa, a partir da França. Esta aparecia, assim, desprovida de qualquer originalidade histórica, inserida naqueles movimentos cíclicos que de tempos em tempos assolavam a história humana. Um gesto significativo desponta, nesse particular, caracteristico do método peculiar construído por Chateaubriand para inventar a si mesmo e narrar sua trajetória. Em 1826, ele decidiu publicar o Ensaio sobre as Revoluções na maneira original como o concebera, embora afirmasse discordar inteiramente de seu conteúdo. A idéia (e da sua narrativa) perpassa o texto do ensaio, comparado a um diário de viagem onde fosse registrada não a descoberta de novas paisagens e povos, mas uma transmutação interna, fruto da solidão e do infortúnio. Por outro lado, na comparação entre o prólogo de 1794 e 0 prefácio à edição de 1826, ele nos oferece o testemunho do vertiginoso sentimento de aceleração do tempo que acompanhara aquela primeira escrita. No prólogo original, ele dizia dessa aceleração em sua percepção de si, demarcando o uso pronominal do "eu", como marca da viagem interior e expressão da solidão e da amargura.

Quando eu deixei a França, eu era jovem: quatro anos de sofrimento me envelheceram. Depois de quatro anos, vivendo em retiro no campo, sem um amigo com quem me consultar, sem ninguém que pudesse me ouvir, trabalhando para viver durante o dia e escrevendo, durante a noite, o que me ditavam a tristeza e o pensamento, acabei por esboçar este ensaio. Eu não ignoro os seus defeitos: se o "eu" aí reaparece tantas vezes, é que esta obra foi, desde o início, empreendida por mim, e apenas por mim. Vê-se, ao longo dela, um infeliz que conversa consigo mesmo; cujo espírito vaga de tema em tema, de lembrança em lembrança; um espírito que não tem a intenção de escrever um livro, mas mantém uma espécie de diário regular de suas excursões mentais, um registro de seus sentimentos, de suas idéias. 0 eu, se faz presente em todos os autores que, perseguidos pelos homens, passaram sua vida distantes deles. Os solitários vivem da lembrança e seu coração, como essas espécies de animais que, na falta de alimentos vindos do exterior, se nutrem de sua própria substância. 10

Em 1826, o torvelinho do tempo se passa fora, no campo dos acontecimentos fugidios, que o escritor se esforça por apreender e aprisionar

Eu comecei a escrever o Ensaio em 1794, ele veio à luz em 1797. Muitas vezes era necessário apagar à noite o quadro que eu havia traçado durante o dia: os acontecimentos corriam mais rápidos do que minha pena: sobrevinha uma revolução que colocava por terra todas as minhas comparações; eu escrevia sobre um barco durante uma tempestade, e pretendia pintar como se fossem objetos fixos as margens fugidias que passavam e se desfaziam à sua passagem ${ }^{11}$

\section{Mantendo sempre o contraponto entre seus comentários de 1826 e} o texto de 1794, ele optou por pontilhá-lo com extensas notas, em que critica suas posições anteriores. Nelas, apresenta sua convicção sobre 0 caráter falacioso dos paralelos e afirma sua crença no papel irredutivel da dimensão temporal para a compreensão das distintas sociedades e processos históricos. É lapidar, nesse sentido, a retratação colocada em nota.

0 vício radical de todos estes paralelos, sem falar das esquisitices que eles produzem, é o de supor que a sociedade na época da revolução republicana da Grécia era semelhante à sociedade tal qual ela existe hoje : ora, nada pode haver 
"Le vice radical de tous ces parallèles, sans parler des bizarreries qu'ils produisent, est de supposer que la société à l'époque de la révolution républicaine de la Grèce était semblable à la société telle qu'elle existe aujourd'hui : or, rien n'était plus différent. Les hommes avaient peu ou point de relations entre eux; les chemins manquaient, la mer était inconnue ; on voyageait rarement et difficilement ; la presse, ce moyen extraordinaire d'échange et de communication d'idées, n'était point inventée ; chaque peuple, vivant isolé ignorait ce qui se passait chez le peuple voisin. Comparer la chute des Pisistratides à Athènes (qui d'ailleurs n'étaient que des usurpateurs de l'autorité populaire) à la chute des Bourbons en France ; rechercher laborieusement quelle fut I'influence républicaine de la Grèce sur l'Egypte, sur Carthage, sur I'Ibérie, sur la Scythie, sur la Grande-Grèce, trouver des rapports entre cette influence et l'influence de notre révolution sur les divers gouvernements de l'Europe, c'est un complet oubli, ou plutôt une falsification manifeste de I'histoire. (...)Tout est donc faux dans les parallèles que j'ai prétendu établir ». CHATEAUBRIAND, François-René de. Essai historique, politique et moral sur les révolutions anciennes et modernes, considerées dans leurs rapports avec le révolution françoise. ed. 1826. In : Oeuvres Completes (Garnier, 1861), p.379.

\section{3}

CHATEAUBRIAND, François-René

de. "Républiques Espagnoles ». In: Voyage en Amérique. Vol.VI de Oeuvres Complètes (Garnier, 1861), p.212-221.

\section{4}

"Comme Anglois, les colons des Etats-Unis étoiente déjà accoutumés à une discussion pulique des intérêts du peupele, aux droit du citoyen; au langage et à la forme du gouvernement constitutionnel. Ils étoient instruits dans les arts, les lettres et les sciences; ils partageoient toutes les lumières de leur mère-patrie. Ils jouissoient de l'institution du jury; ils avoient de plus, dans chacun de leurs établissements, des Chartes en vertu desquelles ils s'administroient et se gouvernoient ». CHATEAUBRIAND, François-René de. « Républiques Espagnoles ». Op.Cit., p.212.

\section{5}

"Ont-ils été, dans les vieilles Espagnes, élevés à l'école de la liberté? Ont-ils trouvé dans leur ancien pays les institutions, les enseignements, les exemples, les lumières qui forment um peuple au gouvernement constitutionnel? ». CHATEAUBRIAND, François-René de. "Républiques Espagnoles ». Op.Cit., p.213. de mais diferente. Os homens mantinham pouco ou nenhuma relação entre eles; faltavam estradas, o mar era desconhecido ; viajava-se raramente e com grande dificuldade ; a imprensa, este meio extraordinário de intercâmbio e veiculação de idéias, não havia sido inventada ; cada povo, vivendo isolado, ignorava o que se passava com o povo vizinho. Comparar a queda de Pisistratides em Atenas (...) (que, de resto não eram mais do que usurpadores das autoridades populares) à queda dos Bourbons na França; pesquisar laboriosamente qual foi a influência republicana sobre o Egito, sobre Cartago, sobre a Ibéria, sobre a Cítia, sobre a Grande Grécia, encontrar relações entre esta influência e a influência de nossa revolução sobre os diversos governos da Europa (... isto é um completo esquecimento, ou mais ainda, é uma falsificação completa da história. (...) Tudo é então falso nesses paralelos que eu pretendi estabelecer. ${ }^{12}$

Data de 1827, a primeira publicação do relato da viagem de Chateaubriand à América do Norte, juntamente com sua monumental "epopéia do homem primitivo", Les Natchez, embora este livro, fonte que irrigou todas as suas obras de ficção americana, tenha sido originalmente escrito em 1802. Nele, nosso autor viria a retomar a questão dos paralelismos, e o modo como estes transitavam entre antigos e modernos. Mas, agora, o tema vem executado em outra tonalidade, travejado pelas relações impressas pelo Velho Mundo sobre o Novo, através da colonização européia da época moderna. Diferentes metrópoles constituem diferentes culturas civicas em suas colônias. A comparação coeva traveja-se com a explicação histórica, estabelecendo, desse modo, a partir do paralelo, um paradigma comparativo.

Um exemplo importante desse mecanismo encontra-se no fragmento que ele denominou "Repúblicas Espanholas"13 e que foi por ele acrescentado ao relato da viagem à América do Norte. Que ele fosse publicado em 1827, logo depois do reconhecimento da independência das nações da América Espanhola e Portuguesa e como avaliação política e memorialística de sua vida pública, diz muito sobre a fecunda efervescência desses anos na construção do pensamento de Chateaubriand e de sua viragem na consideração das diferentes texturas do tempo e do devir histórico.

A comparação se estabelece aqui entre República e Monarquia, clivada pelos destinos distintos das duas porções da América. Esta diferença se fundava na própria experiência da colonização, tendo os colonos da América do Norte, egressos das lutas pelas liberdades na mãe-pátria, trazido para o solo americano as sementes de uma fecunda cultura cívica, apta a formatar instituições livres e republicanas. Assim, "como ingleses, os colonos dos Estados Unidos estavam já habituados à uma discussão pública dos interesses do povo, aos direitos do cidadão, à linguagem e à forma do governo constitucional. Eles eram instruidos nas artes, nas letras e nas ciências; eles compartilhavam de todas as luzes de sua mãe pátria. Eles desfrutavam da instituição do júri, eles tinham, além disso, em cada um de seus estabelecimentos, cartas em virtude das quais eles se administravam e se governavam"14. Estas "cartas" foram as bases constitucionais dos Estados que depois se constituíram sob o laço federativo.

Nas colônias espanholas, outro foi o legado dos séculos de colonização, pois a Espanha também transmitiu às suas colônias a sua religião, seus hábitos, costumes e preconceitos, que não incluiam, como na América do Norte, a experiência das liberdades públicas. Assim, perguntava Chateaubriand, puderam ser, os colonos "das velhas Espanhas, educados na escola da liberdade? Encontraram eles, em seu país de origem, as instituições, os ensinamentos, os exemplos, as luzes que formam um povo para o governo constitucional?".15 


\section{6}

" (...) Une population catholique, soumise à um clergé nombreux, riche et puissant; une population mêlée de deux millions neuf cent trent-sept mille blancs, de cinq millions cinq cent dix-huit mille nègres et mulâtres livres ou esclaves, de sept millions cinq cent trente mille Indiens; une population divisée en classe noble et roturière, une population disséminée dans d'immenses forêts, dans une variété infinie de climats, sur deux Amériques et le long des côtes de deux oceans; une population presque sans liens nationaux et ans intérêts communs (...)».CHATEAUBRIAND, François-René de. "Républiques Espagnoles ». In : Voyage en Amérique. Vol.VI de Oeuvres Complètes (Garnier, 1861), p.213

\section{7}

A idéia de que a Guerra de Espanha é o início de seu trabalho memorialístico é do próprio Chateaubriand.. Os escritos sobre o Congresso de Verona vieram à luz, pela primeira vez, em 1838. Ver CHATEAUBRIAND, François-René de. Congrès de Vérone. Guerre d'Espagne. Négociations. Colonies espagnoles. Edition originale. Leipzig ; Paris : Brockhaus : Avenarius, 1838. Uma primeira edição das Memórias foi publicada em 1841. A edição utilizada aqui é, Oeuvres complètes, vol. 12, Le congrès de Vérone ; Guerre d'Espagne Fac-sim. de l'éd. de, Paris : Garnier, 1861). Para um profundo e erudito estudo sobre a obra política de Chateaubriand ver a Introdução do especialista CLÉMENT, Jean Paul em Chateaubriand politique - François-René de Chateaubriand De I'Ancien Régime au Nouveau Monde- Ecrits politiques. Paris: Hachette, 1997. Do mesmo especialista, ver a introdução de François-René de Chateaubriand, Grands écrits politiques. Paris: Imprimerie National, 2005.

\section{8}

" On paraît avoir, mal à propos, confondu avec les Mémoires qui ne doivent paraître qu'après ma mort, ce récit du congrès de Vérone et de la guerre d'Espagne ; je ne dis aujourd'hui que ce que je puis dire de mon vivant ; à la tombe le reste. ». CHATEAUBRIAND, François-René. Le congrès de Vérone; Guerre d'Espagne. Op.Cit. p.3
A resposta era sem dúvida pela negativa, fazendo os descendentes de Cortez e Pizarro, muito diferentes e muito menos preparados para o autogoverno do que os colonos ingleses da América do Norte, por que a Espanha havia transportado ao Novo Mundo sua religião, costumes, idéias e preconceitos. Por isso, eles formavam "uma população católica submissa a um clero numeroso, rico e poderoso; uma população mestiça de dois milhões novecentos e trinta e sete mil brancos; de cinco milhões, quinhentos e dezoito mil negros e mulatos livres ou escravos; de sete milhões quinhentos e trinta mil índios; uma população dividida em classe nobre e plebéia, disseminada por florestas imensas, em uma variedade infinita de climas, ao longo de dois continentes e dois oceanos; uma população quase sem laços nacionais e sem interesses comuns (...)".16

Pelas evidências anteriores, parece-nos legítimo supor que as indicações que demarcaram a mudança das concepções de Chateaubriand sobre o tempo foram todas elas explicitadas nessa mesma conjuntura crítica de sua vida. Foram elas: a decisão de anotar extensamente o Ensaio sobre as Revoluções, deixando o testemunho sobre a radical novidade da Revolução Francesa sobre todas as que a precederam; a publicação do relato de sua Viagem à América, também perpassado de extensas anotações sobre o tempo presente, (inclusive comparações entre as duas Américas) e a escrita do texto sobre o Congresso de Verona-Guerra de Espanha, em tom que fazia convergir o testemunho político e o tom memorialístico. $\mathrm{Na}$ etapa que então se encerrava, cumpria-se, para usar uma metáfora tão cara a ele, uma longa travessia. Parece-nos que o desdobramento da crise espanhola desempenhava nela uma paragem essencial, não apenas entre duas concepções do tempo, mas também no estabelecimento de uma relação caracteristica entre "escrita de si" e "escrita da história" que fez dele uma referência fundamental para o vertiginoso movimento memorialístico que nele se espelhou. ${ }^{17}$ Isso por que os escritos de Chateaubriand, o Congresso de Verona e a Guerra de Espanha tratam em profundidade da crise espanhola, da situação das Américas, e evidentemente, dos interesses geo-políticos e diplomáticos da França. Fazem-no, entretanto, na chave testemunhal que caracterizará a re-fundação do gênero autobiográfico em sua interface com a escrita da história : o compromisso com a " veracidade ", o fornecimento de abundante base documental, a preocupação com o julgamento dos pósteros, a colocação em evidência do papel do indivíduo e de suas escolhas no devir histórico.

É assim que, já na apresentação do relato sobre o Congresso de Verona, ele introduz o leitor a esta tensão entre história e memória, ao dizer que, embora versando sobre fatos vividos, o texto difere das Memórias, por ser publicado ainda em vida, sugerindo uma maior parcimônia em suas revelações: «parecem ter, erroneamene, confundido com as Memórias que não devem ser publicadas antes da minha morte, este relato sobre o Congresso de Verona e a Guerra de Espanha; eu não digo hoje mais do que posso dizer em vida; à tumba deixo o resto."18 Embora escrevendo sobre fatos vividos por ele, ele afirma buscar a "imparcialidade do historiador", disposição que não elimina a tensão entre as duas facetas (o memorialista e o historiador), como se percebe no enigma semântico que ele se propôs.

Vale a pena dizer que ao falar de mim, eu me servi alternadamente dos pronomes "eu" e "nós": "nós", como representante de uma opinião; "eu" quando acontece de eu estar pessoalmente em cena ou de exprimir um sentimento individual. O "eu " 
19

"Vaut-il la peine que je dise qu'en parlant de moi je me suis tour à tour servi des pronoms nous et je : nous comme représentant d'une opinion, je quand il m'arrive d'être personnellement en scène ou d'exprimer un sentiment individuel. Le moi choque par son orgueil ; le nous est un peu janséniste et royal. II suffit qu'on soit prévenu de ce mélange de pronoms : ils se corrigeront peut-être l'un par l'autre". CHATEAUBRIAND, François-René. Le congrès de Vérone; Guerre d'Espagne. Négociations. Colonies espagnoles. Edition originale. Leipzig; Paris : Brockhaus : Avenarius, 1838. p.4

20

"Nous ne croyons pas être de cette petite classe d'hommes qui, selon Sénèque, surnagent et se débattent parmi les flots des siècles ; nous ne croyons pas non plus que les choses de la terre intéressent les morts au delà de la tombe ; mais, par une illusion de notre existence actuelle, nous tenons plus à notre mémoire qu'au jour où nous vivons, notre mémoire, si elle dure, devant être plus longue que notre vie : or, comme nous ne serons pas auprès d'elle pour la protéger, il faut qu'elle porte en soi le moyen de se défendre ». CHATEAUBRIAND, François-René. Le congrès de Vérone; Guerre d'Espagne, p.37.

\section{1}

" (...) en France, tout s'était fait par le peuple ; en Espagne, tout se faisait par l'armée (...). La Péninsule est une espèce d'empire romain ; les révolutions s'y réduisent à des troubles prétoriens et à des élections légionnaires». CHATEAUBRIAND, François-René. Le congrès de Vérone; Guerre d'Espagne, p.19.

\section{2}

"Le Piémont et le Portugal, imitant Naples, proclamèrent la constitution de Cadix. Grenoble et Lyon s'émurent ; les cortès applaudirent. Toreno nous attaque en termes violents; Alpuente propose d'intervenir dans les affaires d'Italie ; Moreno Guerra veut rompre avec l'Europe et chasser de Madrid les ministres de l'Alliance. Les vaincus de tous les pays se réfugient en Espagne ; ils y reçoivent encouragement et secours". CHATEAUBRIAND, François-René. Le congrès de Vérone; Guerre d'Espagne. Op.Cit. p.23

\section{3}

"Plagiaires aussi de l'empire, les Espagnols empruntèrent le nom de bataillon sacré à la retraite de Moscou, ainsi qu'ils étaient bouffonesques de la Marseillaise, des sanculotides , des propos de Marat, des diatribes du Vieux Cordelier, toujours rendant les actions plus viles, le langage plus bas. Ils ne produisaient rien, parce qu'ils n'agissaient point par l'impulsion du génie national : ils traduisaient et jouaient perpétuellement notre révolution sur le théâtre espagnol ». CHATEAUBRIAND, François-René. Le congrès de Vérone; Guerre d'Espagne, p.31 choca por seu orgulho, o "nós " é um pouco jansenista e real. É suficiente que se esteja prevenido por esta mistura de pronomes: eles provavelmente se corrigirão um ao outro. 19

0 convívio tenso entre as duas dimensões e o resultado admirável que dai decorrer prefiguram já a maestria daquele que seria um dos fundadores da forma moderna de autobiografia. Nela, a história é vista como um palco em que a ação humana se submete ao julgamento dos pósteros.

\footnotetext{
Nós não acreditamos pertencer a essa pequena classe de homens que, segundo Sêneca, bóiam e se debatem na espuma dos séculos; nós não acreditamos, tampouco, que as coisas da terra interessem aos mortos, além túmulo; mas, por uma ilusão de nossa existência atual, nós estamos mais presos à nossa memória do que ao momento presente, já que nossa memória, se ela durar, deve ser mais longa que nossa vida. Ora, como nós não estamos lá para protegê-la, é preciso que ela seja dotada de meios de se defender. 20
}

As análises e justificativas deixadas por Chateaubriand sobre a intervenção francesa na Espanha parecem representar um ponto de inflexão no seu pensamento sobre a revolução, desdobrando de certa forma a cesura explicita em suas notas de 1826 ao Ensaio sobre as Revoluções Antigas e Modernas. Dentre os múltiplos e contraditórios sentidos que o termo assumiu no pensamento de Chateaubriand, a crise revolucionária na Espanha aparece freqüentemente em sua escrita sob o signo de sua semelhança com a Revolução Francesa. Tal semelhança adquire, entretanto, a tintura da imitação, da repetição farsesca. Os acontecimentos da Espanha apareciam como uma cópia servil dos eventos da Revolução Francesa: lá havia também os clubes, as moções, os assassinatos, as grandes proclamações. Ele assinalava, porém, uma diferença importante - "na França, tudo se fazia em nome do povo, na Espanha, tudo se fazia por intermédio do exército (...) A Península é uma espécie de Império Romano : as revoluções ai se reduzem a perturbações pretorianas e eleições legionárias (...) ${ }^{21}$. Este caráter, entretanto, não isentava a Revolução Espanhola de seu caráter intrinsecamente contagioso, pois era capaz de animar as forças da soberania do poço em diversos pontos da Europa, como o demonstravam os levantes recentes nos estados italianos, os de Portugal e as conspirações de que se tinha noticia na própria França. Suas reverberações eram já sentidas em todo o continente, onde "o Piemonte e Portugal, imitando assim como Nápoles, proclamaram a constituição de Cádis. Grenoble e Lyon se agitaram, as cortes aplaudiram. Toreno nos ataca em termos violentos; Alpuente propõe intervir nos negócios da Itália; Moreno Guerra quer romper com a Europa e expulsar de Madri os Ministros da Aliança. Os vencidos de todos os paises se refugiam na Espanha, onde recebem encorajamento e abrigo".22

Em outro ponto, enfatizando o mimetismo da rebelião espanhola em relação aos acontecimentos revolucionários da França, ele apontava: "(...) Imitadores também do Império, os espanhóis emprestaram a expressão batalhão sagrado da retirada de Moscou, assim como parodiaram a Marselhesa, o sanculotismo, as proposições de Marat, as diatribes do Velho Jacobino, sempre tornando as ações mais vis e a linguagem mais baixa. Eles não produziram nada, porque eles não agiam pelo impulso do gênio nacional: eles traduziam e representavam perpetuamente nossa revolução em cena espanhola."23 
24

"Nos têtes sans corps et nos carcasses sans têtes, vues à distance, lorsqu'on ne pouvait plus distinguer leur horreur, offraient du moins, par l'arrangement symétrique de l'immense ossuaire, de l'effrayant et du gigantesque ; il n'en était pas ainsi dans la Péninsule (...): les hommes de cette Péninsule avaient franchi deux de leurs siècles d'un plein saut, pour rejoindre notre histoire, d'un côté à Voltaire, de l'autre à la Convention; mais ces siècles supprimés revenaient, reprenaient leur empire et troublaient l'ordre violemment établi ". CHATEAUBRIAND, François-René. Le congrès de Vérone; Guerre d'Espagne. Négociations. Colonies espagnoles. Edition originale. Leipzig ; Paris: Brockhaus: Avenarius, 1838. p.31.

\section{5}

"Jadis les révolutions ont été réprimées, parce qu'en général elles procédaient des passions, non des idées : la passion meurt comme le corps, l'idée vit comme l'intelligence ; ainsi on retient une passion, on n'arrête pas une idée. L'idée révolutionnaire émise par nous en 1789, après avoir parcouru l'Europe et l'Amérique, nous revenait d'Espagne ". CHATEAUBRIAND, François-René. Le congrès de Vérone; Guerre d'Espagne. Op.Cit. p.19

\section{6}

"Mais la nature s'arrete-t-elle ? Mais le idées restent-elles stationnaires? Mais les peuples se taisent-ils? (...) Non : en Europe, les vieilles générations sont prêtes à disparoître ; en Amérique, des nations nouvelles se forment, et cette Amérique, qui a reçu de nous des constituions, nous les renvoie. Le mouvement est donné, et ne sera point suspendu ; nous serons surpris (...) par des révolutions qui seront les denières de l'ancien ordre de choses. Ces révolutons arrivent ; elles sont à notre porte. (...) nous n'avons pas voulu conduire les événements, nous serons conduits para eux ".CHATEAUBRIAND, François-René, 19 de julho 1825. Fechamento da sessão da Câmara dos Pares, Polémique (fin) Opinions et discours politiques; Fragments divers. In : Oeuvres complètes de Chateaubriand. Paris :Garnier, [s.d.], vol.8. p.150.

\section{7}

"Que falloit-il faire pour ne pas être envahi en Europe para le souveraineté dupeuple, pour éviter la lutte entre des républiques dans la force de l'âge et des monarchies affoiblies par le temps et le révolutions? Nous le répéterons jusqu'à satiété, parce que la question étoit là tout entière : il falloit favoriser autant que psosible l'établissement des monarchies constitutionnelles en Amérqie et maintenir franchement celles qui existent en Europe. CHATEAUBRIAND, François-René, 28 de outubro de 1825. Polémique (fin) Opinions et discours politiques; Fragments divers. Op.Cit. p.130.
A revolução espanhola, ao parodiar a revolução francesa, representava para ele, na verdade, uma dramática (e malograda) tentativa de acompanhar a marcha do século, que retirava dos espanhóis o melhor de suas glórias passadas, sem nada Ihes oferecer no presente. Reforçando, com sarcasmo, a idéia de paródia, dizia ele: "nossas cabeças sem corpos e nossas carcaças sem cabeças, quando não podiamos mais distinguir seu horror, ofereciam ao menos, pelo arranjo simétrico do imenso ossuário, algo de assustador e de gigantesco. Não era assim, na Península [...] : os homens desta Península haviam transposto dois séculos em um salto, para vir ao encontro da nossa história - de um lado, Voltaire; de outro, a Convenção; mas estes séculos suprimidos retornavam, retomavam seu império e perturbavam a ordem violentamente estabelecida". 24

Embora essa estratégia narrativa possa soar às vezes como uma reciclagem do "paradigma dos paralelos", torna-se logo evidente que, neste caso, o recurso é apenas uma tênue roupagem para sublinhar exatamente a idéia oposta: a de que a história não se repete e as revoluções tampouco. 0 ponto importante não é a similaridade, mas a afirmação da diferença, muito embora exista um nexo visivel entre os distintos episódios da maré revolucionária, levando-o a focalizar o contato e a reversividade desses processos históricos. As revoluções modernas não apenas são diferentes das revoluções antigas; esta diferença se funda em algo que é intrínseco da modernidade e que estabelece o seu caráter "contagioso": ela não vem dos paralelismos da história, mas da capacidade de propagação das idéias. Assim, afirmava ele "...antes, as revoluções eram reprimidas por que, em geral, elas provinham das paixões, não das idéias: a paixão morre, como o corpo, a idéia vive, como a inteligência. Pode-se refrear uma paixão, não se pode prender uma idéia. A idéia revolucionária emitida por nós em 1789, depois de haver percorrido a Europa e a América, retornava a nós a partir da Espanha"25.

A circulação das idéias e das pessoas fermentava os ideários políticos de forma incontrolável. Discursando na Câmara dos Pares no final de 1826, ele dizia, "(...) por acaso a natureza se detém? As idéias permanecem estacionárias? Os povos se calam? (...) Não, na Europa as velhas gerações estão prestes a desaparecer. Na América, nações novas se formam, e esta América, que recebeu de nós as constituições, no-las reenvia. 0 movimento está dado e não será suspenso; nós seremos surpreendidos (...) por revoluções que serão as últimas da antiga ordem. Estas revoluções se aproximam. Elas estão às nossas portas (....) nós não quisemos conduzir os acontecimentos, nós seremos conduzidos por eles"26

Em sua vertente americana, a ameaça revolucionária trazia consigo a forma republicana, o que vinha a representar uma frontal ameaça às monarquias restauradas. Enlaçavam-se, para ele, os destinos da monarquia européia, com aqueles dos regimes que seriam instaurados nas nações americanas. Assim sendo, perguntava ele, "(...) o que seria necessário fazer para não ser invadido na Europa pela soberania do povo, para evitar a luta repúblicas na força da idade e monarquias enfraquecidas pelo tempo e pelas revoluções?". Para responder com veemência: "(...) nós o repetiremos até a saciedade por que a questão reside inteiramente nisso: é preciso favorecer tanto quanto possivel o estabelecimento de monarquias constitucionais na América e manter francamente aquelas que existem na Europa" 27

Agir nesse sentido era também essencial para, utilizando a oportunidade de intervenção na Espanha em 1822, trazer de volta a França ao cenário político e militar europeu. Concentrando-nos inicialmente nesse espaço de 
28

Cf. Intervenções de Chateaubriand em MAUROIS, André. René ou la vie de Chateaubriand. Paris: Bernard Gasset, 1938, p.336-361.

29

Canning 14 janvier 1823, citado em MAUROIS, André. 0p.Cit. p.343. experiência, propiciado pela crise espanhola e pela possibilidade de intervenção política em seu decurso, sumarizemos, brevemente, os principais pontos da estratégia desenvolvida por Chateaubriand na crise espanhola.

\section{Um exército para a monarquia}

Vista em seus múltiplos planos, a estratégia de Chateaubriand partia de uma avaliação da conjuntura internacional em que a defesa da monarquia constitucional nos dois mundos era o fundamento da recuperação de seu prestígio político no concerto europeu. A monarquia não devia ser apenas restaurada, no sentido da elevação ao poder dos reis legítimos, mas reinventada sob uma forma de constitucionalismo mitigado, que mantivesse a câmara dupla e uma grande parcela de poder real.

A intervenção na Espanha aparecia, inicialmente, como uma hábil maneira de alinhar uma forte corrente de opinião publica a favor da monarquia, dando a Luis XVIII um exército e à França uma vitória militar, no território onde Napoleão tivera uma de suas mais importantes derrotas políticas. É assim que, ao defender o direito de intervenção e a sua oportunidade, diante daqueles que temiam os riscos de uma derrota francesa ele argumentava: "não vos esqueçais jamais que, se a guerra com a Espanha, tem, como todas as guerras, seus inconvenientes e perigos, ela terá para nós uma vantagem imensa: ela nos criará um exército. Faltava, talvez, ainda, alguma coisa para a reconciliação completa dos franceses: ela se cumprirá na frente de batalha". E ainda " (...) Os companheiros de armas tornam-se rapidamente amigos ... 0 rei, com generosa confiança, confiou a bandeira branca aos capitães que haviam feito triunfar outras cores ; eles Ihe ensinarão o caminho da vitória, pois jamais esqueceram o caminho da honra " ${ }^{28}$ No mesmo sentido, ao defender a intervenção, em carta a George Canning de 1823, ele afirmava: "a guerra, dizeis, poderá subverter nossas instituições ainda mal consolidadas? Pode ser que sim, mas há duas maneiras de fazer perecer um governo: uma pelos reveses militares, a outra pela desonra. Se a Espanha revolucionária puder se gabar de ter feito tremer a França monárquica, se o cocard branco se retirar diante dos descamisados, ficará a recordação da potência do Império e dos triunfos cocard tricolor ; ora, calculai o efeito que terá esta recordação para os Bourbons. (...) Um sucesso ligará para sempre o exército ao rei e fará com que toda a França acorra ao chamado das armas ". ${ }^{29}$ Concentrado em tirar o melhor partido desse efeito, Chateaubriand, na qualidade de Ministro de Estado ocupou-se pessoalmente de alguns detalhes do preparo militar, incluindo-se ai a escolha dos comandos, para que se mesclassem na frente de batalha, em torno do rei, as várias clivagens politicas que recortavam o exército.

Se a guerra da Espanha era vista como uma oportunidade para congregar o exército em torno de Luis XVIII, Chateaubriand insiste que ela não deveria ser identificada com a restauração do absolutismo monárquico nos moldes do Antigo Regime. A restauração da legitimidade monárquica espanhola em torno de Fernando VII era um passo que deveria ser completado pela criação de uma fórmula constitucional aceitável para a Espanha continental e pela mediação da Independência das Colônias.

Havia, entretanto, uma peça importante a ser movida no tabuleiro das negociações em Verona, e esta também se referia a interesses disseminados nos dois mundos: a questão do tráfico africano. 
30

CHATEAUBRIAND, François-René. Le congrès de Vérone; Guerre d'Espagne. Négociations. Colonies espagnoles. Edition originale. Leipzig : Paris : Brockhaus : Avenarius, 1838. p.36-48.
31

"L'Angleterre avait peur que le commerce auquel elle avait renoncé à regret ne tombât entre les mains d'une autre nation; elle voulait forcer la France, I'Espagne, le Portugal, la Hollande à changer subitement le régime de leurs colonies, sans s'embarrasser si ces Etats étaient arrivés au degré de préparation morale où l'on pouvait donner la liberté aux nègres, en abandonnant à la grâce de Dieu la propriété et la vie des blancs. " CHATEAUBRIAND, François-René. Le congrès de Vérone; Guerre d'Espagne. p.39.

\section{2}

"(...) il fallait que nous eussions jeté vite dans la mer Pondichery, l'île de Bourbon, Cayenne, la Martinique et la Guadeloupe, nous qui n'occupions que ces misérables points disjoints de notre sol, sur la surface du globe ". CHATEAUBRIAND, François-René. Le congrès de Vérone; Guerre d'Espagne. p.39.

\section{A pressão britânica em Verona: o tráfico africano}

$\mathrm{Na}$ reconstituição feita por Chateaubriand, a insistência da Inglaterra em introduzir a questão do tráfico negreiro em todos os encontros internacionais, desde Viena, fazia deste um dos temas mais espinhosos na relação entre as potências européias, que possuiam interesses divergentes nesse tema.

0 tema chegou ao Congresso de Verona em 24 de novembro de 1822, através de duas memórias redigidas pelo Duque de Wellington. A primeira relacionava-se à abolição do tráfico africano e a segunda tratava do combate à pirataria nos mares da América, forçando habilmente uma aproximação entre as duas práticas - o tráfico negreiro e a pirataria. 30

A investida britânica desdobrava-se em três pontos : a proposta de impor um direito de visita sobre as embarcações suspeitas de estarem engajadas no tráfico, a equalização do crime de tráfico negreiro ao crime de pirataria, com as puniçoes correspondentes (inclusive a pena de morte) e a imposição de embargo contra mercadorias provenientes de paises que mantivessem o tráfico.

Se ativar a pressão contra o tráfico negreiro nos congressos intraeuropeus constituia um elemento essencial da política externa britânica, a resistência contra essa pressão fez-se também peça-chave da política francesa defendida por Chateaubriand em Verona, não apenas por que ela incorporava interesses vitais dos grupos que pretendiam reativar a exploração das "ilhas de açúcar" no Caribe francês, mas porque ela representava também um ponto de convergência a ser explorado no interior do Império Espanhol, facilitando a aproximação entre os dois ramos da monarquia bourbônica e os interesses coloniais ligados ao tráfico.

Assim, aceitando o principio geral proposto (a condenação moral do tráfico) a França opôs-se decididamente às pressões inglesas, tanto no que se referia ao direito de visita, como à assimilação do crime de tráfico ao da pirataria. Sobre o tema, Chateaubriand afirmava ironicamente que "a Inglaterra temia que o comércio ao qual ela havia renunciado com tanto pesar, caisse nas mãos de outras nações" [e que ela ansiava por] "forçar a França, a Espanha, Portugal e a Holanda a mudar subitamente o regime de suas colônias, sem se preocupar se estes estados haviam alcançado o grau de preparo moral onde se pudesse dar a liberdade aos negros, abandonando à graça de Deus a propriedade e a vida dos brancos" 31 . A Inglaterrra valia-se de sua superioridade econômica e de sua presença no mundo colonial, pretendendo que os franceses pudessem "jogar ao mar Pondichery, a Ilha de Bourbon, Caiena, a Martinica e Guadalupe, [...] estes miseráveis pontos esparsos de nosso solo na superfície de globo. „32

Analisando o caráter político das motivações inglesas, Chateaubriand procurava explorar as incoerências das suas lideranças políticas, particularmente dos tories, inimigos das liberdades politicas internamente e defensores hipócritas das liberdades na política internacional. Assim eram o "Marquês de Londonderry, o Duque de Wellington, inimigos das franquias em seu pais, M. Canning, discipulo de William Pitt e opositor da reforma parlamentar, todos esses tories adversos durante trinta anos às moções de Wilberforce, haviam se tornado apaixonados pela liberdade dos negros, amaldiçoando a liberdade dos brancos : os ingleses, os ingleses brancos eram vendidos como escravos na América num tempo tão próximo de nós quanto o de Cromwell. 0 segredo dessas contradições está nos interesses privados e no gênio mercantil da Inglaterra, é isto que é preciso 
33

"Le marquis de Londonderry et le duc de

Wellington, ennemis des franchises de leur pays M. Canning, élève de William Pitt et opposé à la réforme parlementaire, tous ces tories adverses pendant trente ans à la motion de Wilberforce, étaient devenus passionnés pour la liberté des nègres, tout en maudissant la liberté des blancs : des Anglais, des blancs ont été vendus pour esclaves en Amérique dans un temps aussi rapproché de nous que le temps de Cromwell. Le secret de ces contradictions est dans les intérêts privés et le génie mercantile de l'Angleterre ; c'est ce qu'il faut comprendre afin de n'être pas dupe d'une philanthropie si ardente et pourtant venue si tard : la philanthropie est la fausse monnaie de la charité ". CHATEAUBRIAND, François-René. Le congrès de Vérone; Guerre d'Espagne. Négociations. Colonies espagnoles. Edition originale. Leipzig; Paris : Brockhaus Avenarius, 1838. p.40.

\section{4}

" ce public suppose au fond de la question des vues mercantiles et un dessein hostile contre le commerce français. (...) on ne peut croire raisonnablement que le peu de colonies que la guerre a laissé à la France soit un objet de jalousie pour une puissance européenne qui possède des îles florissantes dans toutes les mers, de vastes territoires en Afrique et en Amérique et un continent tout entier en Asie». CHATEAUBRIAND, François-René. Le congrès de Vérone; Guerre d'Espagne. p.42.

\section{5}

"Le massacre des colons à Saint-Domingue et l'incendie de leurs habitations ont d'abord laissé des souvenirs douloureux parmi les familles qui ont perdu parents et fortune dans ces sanglantes révolutions. II doit être permis de rappeler ces malheurs des blancs, quand le mémoire anglais retrace avec tant de vérité les souffrances des nègres, afin de faire comprendre comment tout ce qui excite la pitié exerce une puissance naturelle sur l'opinion. II est évident que l'abolition de la traite des nègres eût été moins populaire en Angleterre si elle eût été précédée de la ruine et du meurtre des Anglais dans les Antilles». CHATEAUBRIAND, François-René. Le congrès de Vérone; Guerre d'Espagne. p.42.

\section{6}

" (...) il suffirait de rappeler que cette année même, en pleine paix, le sang français a coulé sur les rivages de l'Afrique. La France reconnaît la liberté des mers pour tous les pavillons étrangers, à quelque puissance légitime qu'ils appartiennent ; elle ne réclame pour elle que l'indépendance qu'elle respecte dans les autres, et qui convient à sa dignité ". CHATEAUBRIAND, François-René. Le congrès de Vérone; Guerre d'Espagne. p.44. compreender para não ser enganado por uma filantropia tão ardente quanto tardia: a filantropia é a moeda falsa da caridade ».33

Em uma memória onde a linguagem irônica se mesclava à grande contundência pela qual a França, liderando as demais potências, se opunha às medidas preconizadas pela Inglaterra, Chateaubriand mencionava a impopularidade dessas medidas junto à opinião francesa, ainda chocada com os acontecimentos de São Domingos. A opinião pública francesa, dizia Chateaubriand, supõe que, " no fundo dessa questão existem pontos de vista mercantis e um desígnio hostil ao comércio francês. [...] não se pode acreditar racionalmente que as poucas colônias que a guerra deixou à França sejam objeto de ciúme para uma potência que possui ilhas florescentes em todos os mares, vastos territórios na África e na América e um continente inteiro na Ásia "34. Se o povo francês parecia menos sensivel à questão da escravidão, dizia ele, a explicação talvez estivesse em que " o massacre dos colonos em São Domingos e o incêndio de suas casas deixaram lembranças dolorosas nas familias que perderam parentes e fortunas nessas sangrentas revoluções. Permita-nos lembrar esses infortúnios dos brancos, quando a memória inglesa rememora com tanta veracidade os sofrimentos dos negros, para que se possa compreender o modo pelo qual tudo aquilo que apela à piedade exerce um poder natural sobre a opinião. É evidente que a abolição do tráfico dos negros teria sido menos popular na Inglaterra se ela tivesse sido precedida pela ruina e pela mortandade dos ingleses nas Antilhas „35.

A equalização do crime de tráfico ao da pirataria, dizia a memória, era também inadequada, dado que tal fato implicaria na aplicação da pena de morte, medida restrita ao sistema juridico de cada estado em particular e que não poderia ser objeto de um fórum internacional.

Quanto ao direito de visita sobre as embarcações suspeitas de tráfico, possivelmente o ponto mais sensivel da reivindicaçao britânica, a memória de Chateaubriand não deixava dúvidas de que ela poderia colocar ingleses e franceses diante da possibilidade de guerra, pois, "bastaria relembrar que neste ano mesmo, em plena paz, correu sangue francês nas costas da África. A França reconhece a liberdade dos mares para todos as bandeiras estrangeiras (...) ela não reclama para si senão a independência que ela respeita nos outros, e que convém à sua dignidade. »36

Desse modo, procurando ambiciosamente colocar-se nos dois mundos, entre os múltiplos significados da revolução, Chateaubriand procurava interpretar, em favor do interesse francês, as possibilidades abertas pelo legitimismo monárquico na Era dos Congressos. Temperá-lo com constituições outorgadas e fazê-lo expandir-se, na Europa e na América, sob a proteção francesa, foi um modo de posicionar-se entre Áustria e Rússia de um lado e a Inglaterra de outro, impondo-se sobre uma Espanha que se tornava periférica na política européia, em um modo perverso de interpretar a polissemia da nação na era das potências. Em outra frente, a oposição às pressões inglesas para a extinção do tráfico, assumia o papel de importante moeda de troca junto aos colonos americanos, ao mesmo tempo em que agradava a uma parte da opinião pública francesa. A libertação de Fernando VII e a restauraçao de seu poder é parte de uma elaborada estratégia mirando a recuperaçao do espaço político da França no contexto europeu e, ao mesmo tempo, buscando retomar, no panorama internacional, os três grandes eixos da politica francesa: Inglaterra, Estados Unidos e Caribe. 
37

" On voit donc que les colonies espagnoles n'ont pont été, comme les États-Unis, poussées à l'émancipation par um principe puissant de liberté ; que ce principe n'a pas eu, à l'origine des troubles, cette vitalité, cette force qui annonce la ferme volonté des nations. Une impulsion venue du dehors, des intérêts politique et des événements extrêmement compliqués, voilà ce qu'on aperçoit au premier coup d'oeil. Les colonies se détachoient de l'Espagne parce que I'Espagne étoit envahie ; ensuite elles se donnoient des constitutions, comme les cortès en donnoient à la mère patrie ; enfin on ne leur proposoit rien de raisonnable, et elles ne voulurent pas reprendre le joug ". CHATEAUBRIAND, François-René. Voyage en Amérique. In: Oeuvres complètes (GARNIER, 1861). p.216.
A monarquia constitucional: uma estratégia para os dois mundos Em longos e reiterados trechos de seus escritos políticos, Chateaubriand enfatizou o enlace entre o destino das monarquias constitucionais na Europa e a possibilidade do enraizamento da instituição monárquica no Novo Mundo. Nesse sentido, a intervenção na Espanha não se confundia, para ele, com a restauração do absolutismo, mas pretendia o estabelecimento de um pacto constitucional que devia completar-se com a implantação de monarquias também constitucionais, encabeçadas por príncipes da Casa de Bourbon, no governo dos novos estados americanos tornados independentes.

A defesa da monarquia como forma adequada às formações ibéricas no Novo Mundo advinha de toda uma complexa avaliação do legado da colonização ibérica (como distinto daquele da colonização britânica), além das peculiaridades das formações sociais americanas.

A revolução e a república não eram formas nascidas no interior da cultura das novas nações da América, do mesmo modo que o foram nos Estados Unidos. Ela foi uma decorrência dos conflitos metropolitanos. Assim, segundo ele, "As colônias espanholas não foram, como os Estados Unidos, conduzidas para a emancipação por um principio natural de liberdade; que este princípio não teve, na origem dos acontecimentos, esta vitalidade, esta força que anuncia a firme vontade das nações. Um impulso vindo de fora, de interesses políticos e de eventos extremamente complicados, é isto que podemos notar ao primeiro golpe de vista. As colônias se separaram da Espanha por que a Espanha foi invadida por Bonaparte; em seguida, elas deram a si mesmas constituições, como as Cortes fizeram com a mãe pátria; por fim, como nada de razoável lhes foi proposto, elas não quiseram retomar seu jugo ॥37. Desse modo, sem raizes profundas em suas próprias organizações sociais, as novas situações republicanas passaram a se assentar sobre os interesses das novas camarilhas de poder, criadas nas lutas pela independência.

Se o Velho Mundo imprimira sua forma ao novo, no decurso da colonização, cabia a ele também fomentar, nas novas entidades políticas nascentes, a monarquia constitucional. Esta parecia para ele uma etapa necessária da educação cívica, dessas formações sociais intrinsecamente clivadas pelas desigualdades étnicas e sociais, em muitas das quais persistia a escravidão.

Retomando, de certo modo, o plano dos paralelos, tanto a desordem revolucionária, como a ordem que deve superá-la partem ambas do Velho Mundo, e a monarquia constitucional deve ser seu instrumento. 0 paralelo não deve obscurecer, porém, os processos novos que a crise revolucionária favorecera. A América, atravessada pela crise revolucionária, havia se tornado campo aberto para o engrandecimento do poderio inglês. Entre 1822 e 1826, dez empréstimos haviam sido concedidos pelos bancos ingleses às novas nações, todos eles em condições vis. Dessa conta, Chateaubriand concluía que, a Inglaterra havia desembolsado a soma de 7 000000 de libras esterlinas, para deixar uma divida de 20978 000. A estes empréstimos, juntava-se a sanha das companhias "empenhadas em explorar as minas, pescar as pérolas, cavar os canais, abrir caminhos, desbravar as terras do novo mundo que parecia estar de novo sendo descoberto (...) a Inglaterra tem vice cônsules nos pequenos portos, cônsules nos portos importantes, cônsules generais, ministros plenipotenciários na Colômbia e no México. Todo o país está recoberto de casas de comércio inglesas, de 


\section{8}

" (...) compagnies destinées à exploiter les mines, pêcher des perles, creuser les canaux, ouvir les chemins, défricher les terres de ce nouveau monde qui sembloit découvert pour la première fois. (...)L'Angleterre a des viceconsuls dans les plus petites baies, des consuls dans les ports de quelque importance, des consuls gééraux, des ministres plénipotentiaires à la Colombie et au Mexique. Tout le pays est couvert de maisons de commerce angloises, de commis-voyageurs anglois, agents de compagnies angloises por l'explortation des mines, de mineralogistes anglois, de militares anglois, de fournisseurs anglois, de colons anglois (...) Le pavillon anglois flotte sur toutes les côtes de l'Atlantique et de la mer du Sud (...) II résulte de ces faits que les anciennes colonies de l'Espagne, au moment de leur émancipatin, sont devenues des pespèces de colonies angloises. "CHATEAUBRIAND, François-René. Voyage en Amérique. In: Oeuvres complètes (GARNIER, 1861). p.216-217.

\section{9}

"La création des nouveaux peuples diminue aussi l'importance relative des anciens peuples. Autrefois il n'y avait dans le monde civilisé que l'Europe ; dans cette Europe, il n'y avait que cinq ou six grandes puissances, dont les colonies n'étaient que des appendices plus ou moins utiles. Aujourd'hui il y a une Amérique indépendante et civilisée ; dans cette Amérique il y a six grands Etats républicains, deux ou trois plus petits, et une monarchie constitutionnelle. Ces neuf ou dix nations, jetées tout à coup dans un des bassins de la balance politique, rendent comparativement le poids des monarchies européennes plus léger. Ce n'est plus une querelle entre la France, l'Autriche, la Prusse, la Russie et l'Angleterre, qui fera le destin de la société chrétienne. La diplomatie, le principe des traités de commerce et d'alliance, le droit politique, vont se recomposer sur des bases nouvelles. Les vieux noms, les vieux souvenirs perdent aussi de leur autorité au milieu des récentes générations, au milieu des jeunes espérances d'un univers qui se forme dans d'autres idées ". CHATEAUBRIAND, François-René de. Polémique. In : Oeuvres complètes. Tomo VIII. (GARNIER, 1861). p.129. comissários de viagens ingleses, de agentes de companhias inglesas para a exploração das minas, de mineralogistas ingleses, de militares ingleses, de fornecedores ingleses, de colonos ingleses (...). 0 pavilhão inglês flutua em todas as costas do Atlântico e dos mares do Sul (...) As antigas colônias da Espanha, no momento de sua emancipação, tornaram-se uma espécie de colônias inglesas." 38

Desse modo, a intervenção legitimista e constitucional na Espanha e o estabelecimento de monarquias constitucionais na América eram faces da mesma moeda, onde se buscava uma espécie de ponte entre dois tempos e entre dois mundos, conformando o modo peculiar de Chateaubriand interpretar o interesse nacional da França no panorama mundial em que a hegemonia inglesa se estabelecia de modo ameaçador. Se a liberdade do homem primitivo americano havia sido o sonho da sua juventude, trazer para a América a liberdade dos modernos na forma da monarquia constitucional seria o grande sonho de sua idade madura.

A impossibilidade da consecução desse objetivo viria a se traduzir em outras variações, sombrias e melancólicas, do tema do tempo e das revoluções.

\section{De tempos e revoluções}

Em 1826, René de Chateaubriand (1768-1848) traduzia a amargura do malogro dessa iniciativa, tratando em tom sombrio a Europa e a América. Não mais era o Velho Mundo que se renovava fazendo florescer a cepa monárquica no continente americano. Ao contrário, as novas repúblicas revertiam sobre a Europa provocando temores e deslocando o lugar do velho continente como protagonista da história.

A criação de novos povos diminui a importância relativa dos povos antigos. Antes, não havia no mundo civilizado senão a Europa; nesta Europa, não havia senão cinco ou seis grandes potências, cujas colônias não eram senão apêndices mais ou menos úteis. Hoje, existe uma América independente e civilizada; nesta América existem seis grandes Estados republicanos, dois ou três menores e uma grande monarquia constitucional. Estas nove ou dez nações, lançadas de um só golpe em um dos pratos da balança politica, reduzem comparativamente o peso das monarquias européias. Não é mais uma querela entre a França, a Áustria, a Prússia, a Rússia e a Inglaterra, que modificará o destino da sociedade cristã. A diplomacia, o princípio dos tratados de comércio e de aliança, o direito político, vão se recompor sobre novas bases. Os velhos nomes, as velhas lembranças perdem muito de (...) sua autoridade em meio às recentes gerações (...) [e] em meio a jovens esperanças de um universo que se forma de outras idéias. 39

É a melancolia e o sentimento da perda que tinge agora a avaliação das relações entre os dois continentes, revestindo-a de cores sombrias. À ampliação do número de nações independentes no Novo Mundo, desligando-se de suas antigas metrópoles, correspondia não mais o avanço das luzes e da civilização, mas uma redução do prestígio e da autoridade do velho continente. $A$ inexorabilidade do tempo e a inevitabilidade das mudanças são aqui em um emaranhado de paradoxos: a Europa, centro irradiador das idéias que formavam o mundo civilizado, enfraquecia-se, perdia energias, precisamente em razão da expansão daquelas idéias e sua materialização em uma "América independente e civilizada". Desse modo, a reflexão sobre a dinâmica do tempo articula o velho e o novo, o antigo e o moderno, em peculiar e contraditória sincronia

É notório que um dos temas centrais da reflexão é o temor da expansão da forma republicana no continente americano, temor que 
40

"Sous un point de vue politique plus élevé, on peut prédire que la république de SaintDomingue aura tôt ou tard des soeurs dans les Antilles et dans la mer des Indes. Les cabinets feront bien de se hâter de prendre les mesures les plus efficaces pour le salut des colons. On doit aussi s'attendre à des nouveautés singulières dans les relations diplomatiques. (...) De tout ceci, il faut bien se persuader que nous arriverons à un changement capital dans la police européenne. La création des républiques du Nouveau Monde, fortifiée par la reconnaissance d'un Etat nègre indépendant, introduira nécessairement dans la diplomatie des principes et des hommes dont les vieilles monarchies sentiront en peu d'années l'influence. ". CHATEAUBRIAND, François-René de. Polémique. In : Oeuvres complètes. Tomo VIII. (GARNIER, 1861). p.161.

\section{1}

"L'Angleterre souffrira moins que les puissances continentales européennes de cette création nouvelle, en raison de sa liberté, de son industrie, de son commerce et de ses diverses possessions. Elle regarde des deux côtés les Amériques sur les deux Océans; elle compte dans I'Inde plus de 80 millions de sujets; elle étend ses colonies sur les côtes de l'Afrique (...) Le cinquième continent se peuple par elle ; dans l'océan Pacifique elle a créé de plus petits royaumes, défendus par une marine, du canon et des forteresses; (...) elle les a créés sur ces mêmes rives habitées il n'y a pas encore cinquante ans par les sauvages meurtriers du grand navigateur qui le premier nous révéla leur existence. "CHATEAUBRIAND, François-René de. Op.Cit. p.92. assume reverberações ainda mais ameaçadoras, quando associado aos ainda recentes e assustadores acontecimentos de São Domingos, onde a República emergira de uma revolução escrava. A ameaça republicana aparecia potenciada pela "republica negra", novidade assustadora que poderia contaminar com seu exemplo largas porções do continente.

De um ponto de vista político mais elevado, pode-se predizer que a República de São Domingos terá, cedo ou tarde, irmãs nas Antilhas e no Oceano Índico. É necessário que os cabinetes se ocupem de tomar medidas mais eficazes para a segurança dos colonos. Deve-se também esperar novidades singulares nas relações diplomáticas. (...) Por tudo isso, precisamos nos convencer de que nós alcançaremos uma mudança capital na política européia. A criação das repúblicas do Novo Mundo, fortalecida pelo reconhecimento de um estado negro independente introduzirá, necessariamente, na diplomacia, principios e homens cuja influência se fará sentir dentro de poucos anos sobre as velhas monarquias. ${ }^{40}$

Prosseguindo na reflexão proposta por Chateaubriand percebemos que, para ele, a extensão do regime republicano pelo continente americano ecoava como ameaça, sobretudo por que favorecia a preeminência inglesa no novo continente. Esta preeminência era assegurada, por um lado, porque a Inglaterra, se colocava na dianteira de um movimento de transformação econômica e também por que soubera ter uma sábia inserção política na crise do sistema colonial ibérico. Por outro, ao longo das guerras da revolução e do Império, a Inglaterra conservara e ampliara seu império colonial.
A Inglaterra sofrerá menos por conta destas mudanças do que as potências da Europa continental, em razão de sua liberdade, de sua indústria, de seu comércio e de suas diversas possessões. Ela descortina as duas costas da América sobre os dois oceanos, ele conta, na Índia, com mais de oitenta milhões de súditos, ela estende suas colônias sobre as costas da África, [...]. 0 quinto continente está sendo povoado por ela; no Oceano Pacifico, ela criou pequenos reinos defendidos por uma marinha, canhões e fortalezas (...)ela as criou nas mesmas margens habitadas, há menos de cinqüenta anos, pelos selvagens que mataram o grande navegador que primeiro nos revelou sua existência. 41

Os elementos aqui colocados em relevo sugerem a permanência da centralidade do espaço americano na reflexão francesa, na longa travessia revolucionária e na sua difícil reinserção no panorama internacional após a Restauração Bourbônica, lugar de onde são emitidas as melancólicas reflexões de Chateaubriand. Mas eles permitem observar uma rotação importante no modo como apareciam, depois da independência das colônias ibéricas, as articulações entre os dois mundos. Emergia daí uma multiplicidade de significados para a idéia de revolução, que abandona aí o campo dos paralelos (Ensaio sobre as Revoluções) e o exercício de paradoxos apresentado em Guerre d'Espagne (as revoluções se imitam?; de que modo elas se propagam?) para chegar à concepção de uma revolução dupla: a do passado, que se devia conjurar e a que se projetava de agora para o futuro, com a qual era preciso lidar inexoravelmente.

A travessia em que ele se empenhou com tanto afinco esteve assim travejada não apenas pelas metamorfoses do sentimento do tempo e das complexas relações entre os mundos nessas distintas temporalidades, como também por uma concepção polissêmica da idéia de revolução.

Esta idéia teve, ao longo de seus escritos, múltiplos avatares, partindo das reflexões que haviam sido suscitadas pelo espaço de experiência 


\section{2}

"La révolution vint nous réveiller : en poussant le Français hors de son lit, elle le jeta dans la tombe. (...) le crime paraissait dans sa franchise. Des orgies au milieu du sang, des scandales qui n'en étaient plus à force d'être horribles; voilà tout. Les femmes du peuple venaient travailler à leurs ouvrages domestiques autour de la machine à meurtre comme à leurs foyers; les échafauds étaient les moeurs publiques et la mort le fond du gouvernement. (...) On disait à un homme : "Tu es chrétien, noble, riche meurs; " et il mourait. ". CHATEAUBRIAND, François-René de. Paris, 5 de dezembro de 1818 Polémique. In : Oeuvres complètes. Tomo VII. Paris: Garnier, s.d.,[ prob. 1861]. p.549.

\section{3}

"Voici la verité : ce n'est oint la liberté, c'est l'égalité absolue qui a été le principe réel et qui forme encore le vrai caractére de la révolution françoise ». CHATEAUBRIAND, François-René de. Polémique. Op.Cit. p.18.

\section{4}

"L'egalité absolue s'accommode du despotisme qui nivelle tout mais ne peut s'arranger d'une monarchie (...) la liberté est le sentiment des âmes elévées : elle produit les grands actions, crée les grandes patries et fonde des instituctions durables; elle se plaït dans l'ordre et la majesté (...) L' égalité absolue ets la passion des petites âmes : elle prend sa source dans l'amour propre et l'envie (...) et tend sans cesse au désordre (...) . CHATEAUBRIAND, François-René de. Polémique. Op.Cit. p.23.

\section{5}

"Aujourd'hui vous avez devant vous une vaste république de plus en plus florissante : sa population augmente chaque jour ; déjà elle s'avance vers l'océan Pacifique et va chercher la Russie sous les glaces du pôle. Là règne le principe de la souveraineté du peuple. L'esprit démocratique de l'Europe ne puise-t-il pas à cette source toujours ouverte? (...) Que les colonies espagnoles passent à l'état républicain, le principe monarchique en Europe n'en sera-t-il pas de plus en plus attaqué ? Chateaubriand ". Paris, 15 de agosto de 1819. CHATEAUBRIAND, FrançoisRené de. Polémique. Op.Cit. p.24. propiciado pela Revolução Francesa e tornando-se cada vez mais diversas, a partir da emergência dos acontecimentos políticos que se sucederam na década de 1820. Nesses textos, em particular nas polêmicas desenvolvidas na imprensa, quando aplicado à revolução francesa, o termo invoca sempre um cortejo de violências, de esmagamento das liberdades antigas, força cega e destruidora que devia ser conjurada. A revolução viera despertar a França e "empurrando o francês fora de seu leito, lançou-o ao túmulo", pois, durante o regime do terror "o crime operava livremente. As orgias no meio do sangue, os escândalos que, de tão horriveis, deixavam de escandalizar; (...) As mulheres do povo vinham executar seus trabalhos caseiros em torno da máquina de morte [a guilhotina] como se estivessem em seus lares; o cadafalso substituia os costumes públicos e a morte era a base do governo. [...] Dizia-se a um homem: 'tu és cristão, rico, nobre: morra (...)', e ele morria".42

Distinguindo as correntes democráticas das liberais, e opondo-as radicalmente, Chateaubriand atribuia às primeiras essa força cega e destruidora, associando-a ao principio da igualdade, oposto ao princípio da liberdade. A igualdade absoluta constituía, segundo ele, "o verdadeiro caráter da Revolução Francesa".43 Mesmo depois da Restauração, o ameaçador sentimento da igualdade grassava ainda na sociedade francesa, rondando a monarquia constitucional e impedindo que ela se consolidasse, pois « a igualdade absoluta se acomoda ao despotismo, que tudo nivela, mas não pode se coadunar com uma monarquia (...) A liberdade é o sentimento das almas elevadas : ela produz as grandes ações, cria as grandes pátrias e funda as instituições duráveis; ela se compraz da ordem e da majestade (...) A igualdade absoluta é a paixão das almas pequenas, ela se origina no amorpróprio e na inveja (...) e tende sem cessar à desordem (...) ${ }^{44}$.

Carregado de outra carga de significações, que vai se tornar cada vez mais freqüente após 1822, a revolução aparece como um processo em curso, inarredável (não necessariamente auspicioso), para o qual seria preciso preparar-se para não ser atropelado por ele. Ela fazia parte de um "espírito geral do século", sobre o qual ele se empenha em alertar seus contemporâneos. Essa revolução não está no passado, ela conecta o presente ao futuro e é preciso se preparar para ela. Nessa dimensão, a revolução é quase um sinônimo da modernidade, fruto da perda do papel da religião como fundamento da monarquia, do desenvolvimento da indústria e da difusão das luzes entre as classes inferiores, tornando-as infensas a todo poder que não se fundamente sobre a razão. Ela é obra das grandes transformações econômicas e sociais do capitalismo e prefigura o que mais tarde seria chamado de sociedade de massas. Nessa qualidade, ela se encarna no poderio econômico da Inglaterra e nas instituições dos Estados Unidos da América, ressoando ameaçadora na possibilidade de sua extensão ao resto do continente.

\footnotetext{
Hoje, tendes diante de vós uma vasta república cada vez mais florescente: sua população aumenta a cada dia, ela já avança sobre o Oceano Pacifico e vai encontrar a Rússia, sob as geleiras polares. Lá reina o princípio da soberania do povo. 0 espírito democrático da Europa não ganha força a partir dessa fonte sempre aberta? (...) Que as colônias espanholas passem ao estado republicano, não significa que o princípio monárquico na Europa seja cada vez mais atacado? (...). 45
}

Fracassada a alternativa de extensão do principio monárquico às antigas colônias espanholas, a revolução que se avizinhava e que se 
confundia com a própria consolidação do poderio inglês, assentava-se após 1822, também naquela outra América, onde se expandia a forma republicana.

Lançai um olhar sobre o mundo e vede o espetáculo que se vos apresenta. As repúblicas ocupam uma arte imensa da terra, nas margens dos dois oceanos ; nestes povos que dispõem de todo o vigor da juventude, nesses países ainda virgens, a civilização aperfeiçoada da velha Europa irá prestar seu socorro à uma natureza potente e enérgica. As máquinas da Inglaterra explorarão as minas da América, que serão, por assim dizer, descobertas por uma segunda vez. Os navios à vapor subirão todos esses rios destinados a facilitar as comunicações, depois de terem sido obstáculos invencíveis. As margens desses rios se cobrirão de cidades e aldeias (...) Nessas florestas, consideradas até então impenetráveis, passarão brevemente os caminhos de ferro (...) esta espécie de carruagens encantadas andando sem cavalos, transportando de cada vez, com uma rapidez extraordinária, cargas enormes e quinhentos ou seiscentos viajantes (...) e o istmo que uniu uma América à outra romperá sua barreira para dar passagem aos navios de um oceano a outro. 46

46

"Jetez un regard sur le monde, et voyez le spectacle qu'il vous présente. Des républiques occupent une immense partie de la terre sur les rivages des deux Océans; chez ces peuples, qui ont toute la vigueur de la jeunesse, dans ces pays vierges encore, la civilisation perfectionnée de l'ancienne Europe va prêter ses secours à une nature puissante et énergique. Les machines de l'Angleterre exploiteront les mines de l'Amérique, découverte pour ainsi dire une seconde fois. Des bateaux à vapeur remonteront tous ces fleuves destinés à devenir des communications faciles, après avoir été d'invincibles obstacles. Les bords de ces fleuves se couvriront en peu de temps de villes et de villages, (...). Dans ces forêts, réputées impénétrables, bientôt passeront, sur des chemins de fer, (...) ces espèces de chariots enchantés marchant sans chevaux, transportant à la fois, avec une vitesse extraordinaire, des poids énormes et cinq à six cents voyageurs. (...) et l'isthme qui unit l'une et l'autre Amérique rompra sa barrière pour donner passage à ces vaisseaux dans I'un et l'autre Océan. ». Paris, 24 de outubro de 1825. CHATEAUBRIAND, François-René de. Polémique. In : Oeuvres complètes. Tomo VIII. Paris: Garnier, s.d.,[ prob. 1861]. p.121.

\section{7}

"Je me suis rencontré entre les deux siècles comme au confluent de deux fleuves ; j'ai plongé dans leurs eaux troublées, m'éloignant à regret du vieux rivage où j'étais né, et nageant avec espérance vers la rive inconnue (...) ". CHATEAUBRIAND, François-René de. Mémoires d'outre-tombe (1848). Paris: Gallimard, Bibliothèque de la Pléiade, II, 1952. p.933-934. Ver também CLÉMENT, Jean Paul. "Présentation " de Chateaubriand. Grands écrits politiques. Paris: Imprimerie nationale, 1993.
Essa revolução, processando-se sob o regime político republicano, dava a este uma força inaudita, desconhecida das repúblicas antigas como aquelas das cidades italianas ou da Holanda. A extensão dessa potência às novas nações da América, tal era o risco que cabia às monarquias constitucionais da Europa conjurar.

Colocada entre as duas acepções de revolução - o desejo de igualdade, emprestado à revolução francesa e a força incontida do capital, representada pelo poderio britânico e pelos Estados Unidos da América - a penetração da idéia republicana nas Américas carregava também esta carga de incendiaria reversividade, fazendo com que a ameaça revolucionária transitasse entre os dois mundos.

Essa concepção virá a ganhar sua plenitude nas suas monumentais memórias, cuja escrita ganhou ritmo precisamente após o encerramento de sua carreira política e dos escritos analisados neste ensaio. As memórias são, na verdade, um grande tratado sobre o enlace entre o tempo da vida individual e o tempo da história. Apesar das tinturas sombrias, esses escritos estão perpassados pelo sentimento de que se vive um tempo novo, em que o futuro resulta de um movimento inexorável e de desfecho desconhecido. A reflexão sobre o passado forma o substrato da identidade humana e de sua orientação diante dos acontecimentos. Ela é necessária para informar a ação dos homens, não para repeti-la em um movimento cíclico ou para compreender seus curiosos paralelismos. Ela se presta a explorar a possibilidade de modificar o ritmo e a direção dos acontecimentos, fazendo a história. A expressão notória dessa idéia é a metáfora recorrente onde 0 tempo é comparado, de diferentes maneiras, ao curso dos rios.

Explorando essa imagem sempre reiterada, o rio do tempo, ele não falava de um espaço contemplativo, mas da perspectiva da ação. $\mathrm{Na}$ formulação que se tornou lapidar, o tempo é um rio, mas o olhar não se demora sobre a turbulência das águas. Ele pousa sobre os movimentos do nadador, que deixa a margem e mergulha, vencendo a turbulência da corrente, fazendo a travessia entre tempos e mundos.

Eu me encontrei entre dois séculos, como na confluência de dois rios; eu mergulhei em suas águas turbulentas, afastando-me a contragosto da velha margem onde eu nasci, nadando com esperança em direção à margem desconhecida. ${ }^{47}$ 
48

Ver evolução dos acontecimentos e comentários de Chateaubriand em MAUROIS, André. René ou la vie de Chateaubriand. Paris: Bernard Gasset, 1938. p.344-350.

\section{9}

Sobre a questão do legitimismo nas Américas, ver GARAVAGLIA, Juan Carlos. Os primórdios do processo de independência hispano americano. In: JANCSÓ, István (org.). Independência: História e Historiografia. São Paulo: Ed. Hucitec/ Fapesp, 2005. p.107-235.

\section{Considerações finais}

No plano da ação, é preciso ressaltar, em primeiro lugar, que a intervenção na questão espanhola foi um retumbante sucesso militar. Armado de um exército de 100.000 homens (os cem mil cavaleiros de São Luis) sob o estandarte monárquico dos Bourbons, a França invadiu a Espanha, colocou fim à experiência constitucional das cortes e restaurou o poder de Fernando VII. Mesclando habilmente comandos que haviam lutado sob Napoleão e comandos realistas, o próprio Chateaubriand se empenhou para que a Europa visse, pela primeira vez em 34 anos, o exército francês marchar sob a flor de lis da monarquia. Os temidos descontentamentos e motins não se manifestaram. 0 exército foi parado na passagem de Bidassoa por cento e cinqüenta militantes franceses e italianos que gritavam palavras de ordem aos soldados, incitando-os a não participarem de uma operação destinada a "recolocar um déspota no trono". A manifestação foi recebida com uma canhonada e dispersa. 0 governo constitucional recuou para Sevilha em março de 1823 e para Cádis, em junho, onde, depois de um mês de resistência dos constitucionais, o forte de Trocadero foi rendido, dando o seu nome a uma batalha e a uma das célebres praças de Paris.

Na Espanha, a despeito das declaradas intenções de Luis XVIII em favorecer uma ordem constitucional moderada, nenhuma força se interpôs de maneira eficaz ao fortalecimento de uma ordem tirânica e ao desenvolvimento de uma onda de perseguições e arbitrariedades. Chateaubriand, que nunca o teve em boa conta, trata Fernando VII como um tirano obtuso, incapaz de compreender os desafios de seu tempo. ${ }^{48}$ Comprometida com o desenrolar dos acontecimentos, a França deixou na Espanha cerca de 45.000 homens, a pedido do Fernando VII, força de ocupação que lá permaneceu até 1828 .

Na América, o processo acabou por afastar as províncias que ainda mantinham lealdade a Coroa Espanhola, na expectativa de uma ordem constitucional que fosse capaz de construir a unidade da nação mantendo as autonomias provinciais em um plano aceitável para as províncias dos dois continentes. A idéia de extensão de monarquias bourbônicas no continente, tinha contra ela oposições de grande monta (embora despertasse também grandes simpatias), a começar pelas soluções republicanas já consolidadas e a concluir pela falta de monarcas legítimos, embora a vaidade extremada de Chateaubriand gostasse de atribuir o fracasso dessa alternativa apenas a sua queda 49 .

A ação significou, na verdade, o fim da concepção que a Santa Aliança havia buscado impor de uma força de contenção contra a França, que emerge do Congresso restaurada em seu prestígio militar, que seria usado diversas outras vezes ate 1871 , em defesa do principio monárquico e da religião católica. A questão espanhola ajudou a catapultar a França de volta para o cenário das decisões européias, rompendo o dique de contenção que contra ela se organizara em 1815.

É preciso, finalmente, mencionar o Império brasileiro, personagem pouco citado nas reflexões de Chateaubriand sobre a Espanha, mas a quem, além de sua influência literária, se ligariam também aspectos importantes de sua artesania política. A reinvenção da monarquia, com legitimidade dinástica em um único pais da América, fez do Império do Brasil um aliado importante da França no continente, aliado do qual muitas vezes o Império brasileiro pode se valer para contrabalançar o poderio britânico, principalmente na questão do tráfico. Por outro lado, vale lembrar que o 
Tratado, assinado por D. Pedro em 1826, reiterando a intenção de terminar o tráfico negreiro até 1831, perdia muito de sua eficácia enquanto a Inglaterra não contasse com a possibilidade de abordar diretamente os navios suspeitos e enquanto a monarquia brasileira pudesse contar com o anteparo das ácidas críticas de setores importantes da governança e da opinião pública francesa, à ação dos cruzadores britânicos no combate ao tráfico, situação que, com diferentes niveis de intensidade, manteve-se até a Revolução de 1848 e a definitiva abolição da escravidão nas colônias francesas.

Desse modo, o rio do tempo executava aqui também seus caprichos, e a travessia para as liberdades constitucionais carregou consigo possibilidades também renovadas ao comércio negreiro, graças, pelo menos em parte, à sagacidade de Chateaubriand. Nesses tempos de crise, erráticos e contraditórios, o tempo se acelerava e as significações se multiplicavam, suscitando um olhar do presente para o futuro, e fazendo aparecer o passado com novas tinturas e possibilidades. Era um tempo capaz de envelhecer os homens e os povos, mas era também muito propício à História. 